\title{
The South, the Suburbs, and the Vatican Too: Explaining Partisan Change among Catholics
}

\author{
John Barry Ryan \\ Assistant Professor \\ Department of Political Science \\ Stony Brook University \\ Stony Brook, NY, USA 11794 \\ john.ryan@stonybrook.edu
}

\author{
Caitlin Milazzo \\ Assistant Professor \\ School of Politics and International \\ Relations \\ University of Nottingham \\ Nottingham, UK NG7 2RD \\ caitlin.milazzo@nottingham.ac.uk
}

Abstract: This paper explains changes in partisanship among Catholics in the last quarter of the $20^{\text {th }}$ Century using a theory of partisan change centered on the contexts in which Catholics lived. Catholics were part of the post-New Deal Democratic coalition, but they have become a swing demographic group. We argue that these changes in partisanship are best explained by changes in elite messages that are filtered through an individual's social network. Those Catholics who lived or moved into the increasingly Republican suburbs and South were the Catholics who were most likely to adopt a non-Democratic partisan identity. Changes in context better explain Catholic partisanship than party abortion policy post Roe v. Wade or ideological sorting. We demonstrate evidence in support of our argument using the ANES cumulative file from 1972 through 2000.

Keywords: Partisanship; Catholics; Social Networks

Acknowledgements: The authors would like to thank Robert Huckfeldt, Sean Richey, and the three anonymous reviewers for their helpful comments. 
Research on the partisan change that occurred in the latter half of the twentieth century has focused almost exclusively on partisan changes among white Southerners. The change from a solid Democratic to solid Republican voting bloc is well documented and the theories explaining the change are well known (e.g., Carmines \& Stimson, 1989; Green, Palmquist and Schickler 2002). During the same time period another demographic group, Catholics, underwent a similar change. Once solidly Democratic, Catholics are now a swing voting group that both parties covet - about one-fourth of all voters in the 2012 election identified as Catholics according to exit polls. ${ }^{1}$ With a few exceptions (e.g., McDaniel and Ellison 2008; Penning 1986), the reasons for this change have largely gone unexplored.

The bulk of the discussion of the politics of American Catholics centers on abortion. For example, in 2004, Archbishop Raymond Burke of St. Louis made headlines when he said that pro-choice politicians, like the Catholic Democratic presidential nominee John Kerry, should be denied communion. In 2011, Archbishop Timothy Dolan of New York sent a letter to President Obama after the Department of Health Human Services denied a grant funding Catholic programs that aided victims of human trafficking. H.H.S. ended the grant because the programs did not offer women contraception or refer them to abortion providers.

This tension between the Democratic Party and the Catholic Church would have been surprising to casual observers in the early 1960s. Catholics were one of the strongest Democratic voting blocs. The first Catholic presidential nominee, Al Smith, and the first Catholic president, John Kennedy, were both Democrats. By the year 2000, however, Republicans had already seen

\footnotetext{
${ }^{1}$ In the 1970s, 23.7\% of all NES respondents identified as Catholic. In the 1990s, that number had risen to $25.2 \%$. While this increase is small, the difference is statistically significant $(F=5.90 ; p<.02)$.
} 
an increase in support among Catholics and the Republican candidate George W. Bush sent a letter to the U.S. Conference of Catholic Bishops arguing that Republican policies on abortion and stem cell research were more in line with church doctrine (Hillygus and Shields 2008).

It is no surprise then that, when trying to explain declining levels of Catholic partisanship, many would start with abortion and reproductive rights issues (e.g., Adams 1997; Jelen and Wilcox 2003). The focus on abortion, however, is similar to the focus on immigration among Latinos (Barreto and Pedraza 2009). It implicitly assumes that the group is monolithiccaring about only one issue and holding homogeneous attitudes on that issue - which causes the analyst to overlook factors that are potentially more important.

We argue that the actual explanation for mass partisan change has less to do with attitudes towards any single issue and has more to do with where people live. Abortion plays a role, but so does the partisan sorting on ideology that affected all citizens since the 1960s (Fiorina 2006). Most importantly, analysts have overlooked the large role that contextual changes have played in the changing of mass partisanship. Catholics are less Democratic now because fewer Catholics live in northern cities that are heavily Democratic and more live in the South and the suburbs which are more Republican. Fewer Catholics receive predominantly proDemocratic messages in their communities and, as a result, fewer Catholics identify as Democrats.

This paper evaluates the contextual argument looking at partisan change among Catholics in the U.S. using the American National Election Study (ANES) to examine the changes in partisanship in Catholics from 1972 to 2000 . We first show that more Catholics have moved into the South and the suburbs. Next, we show that individuals living in those areas have become less likely to identify as Democratic. Finally, we simulate Catholic partisanship if the contextual 
changes had not taken place. We show large differences between actual partisanship in the 1990s and what partisanship would have looked like without the contextual changes.

\section{Previous Explanations for Partisan Change among Catholics}

Catholic membership in the Democratic Party peaked with the nomination of John Kennedy in 1960. That year over seventy percent of Catholic respondents to the National Election Studies (NES) were Democrats. The link between the Democratic Party and Catholics, however, originates decades earlier. V.O. Key (1955) traces its origins in New England back to the party nominating the Catholic governor of New York, Al Smith, for president in 1928. As parties aligned during the New Deal, President Roosevelt's appointments of Catholics to prominent positions helped ensure Catholics would form part of the Democratic coalition (Campbell et al., 1960). Catholics did not align with a party simply because of nominations and appointments. Catholics were different from most of the country in ways that set them apart and stimulated Democratic allegiance: they were poorer and more urban (McAvoy, 1942).

Poor, urban Catholics joined the Democratic New Deal coalition because of economic interests. They stayed members because their contexts - their neighborhoods and parishes - kept them Democratic. Berelson, Lazarsfeld and McPhee (1954) note that many Catholics would drift to the Republican Party between elections, but the influence of their neighbors would bring them back to the Democratic Party when it was time to vote.

The 1960 election of John F. Kennedy marked the zenith of the Catholic-Democratic alliance, but it would continue for the next few elections. A majority of Catholics backed Ronald Reagan, but Catholics still voted more Democratic than the rest of the country until the 1990s. Partisanship among Catholics is now similar to partisanship among non-Catholics. Forty-four 
years after the nomination of John Kennedy, the Democrats once again nominated a Catholic Senator from Massachusetts. That year fewer than half of Catholic NES respondents identified as Democrats.

What explains this change? The explanations given most often relate to issues. The arguments suggest that Catholic identifiers are more conservative and that as the Democratic Party moved left, Catholics adjusted their partisanship accordingly. For example, Abramowitz and Saunders (2006) argue the partisan change seen within many groups - including Catholics is the result of conservative Democrats deciding that they were in the wrong party. Arguments like this start with the observation that party elites have become more polarized in recent years (Hetherington 2002; McCarty, Poole, and Rosenthal 2006). With this increased polarization, it is easier for liberals and conservatives to recognize which party is liberal and which party is conservative. Once they notice the differences, individuals join the party that best represents their policy preferences. ${ }^{2}$

Of particular importance in the discussion of Catholic partisanship is the issue of abortion. Prior to the Roe v. Wade decision, many Republicans led the pro-choice movement, as leading Democrats did not speak in favor of abortion rights out of deference to the Catholic members of their party (Stimson, 2004). After Roe, the party leaders took their now familiar stand on abortion, and Catholics bishops found themselves actively opposing some Democratic policies. Republicans took this opportunity to argue that their conservative platform - on abortion and other issues - was more in keeping with Catholic values (Leege et al., 2002).

\footnotetext{
${ }^{2}$ For an example of a similar argument in the British context see Milazzo, Adams, and Green (2012).
} 
This could have affected partisanship because abortion had "evolved" as an issue (Adams, 1997). In the case of issue evolution, the changes in elite messages surround an "easy" issue. Easy issues are largely symbolic which voters respond to at a "gut level" (Carmines and Stimson 1980). When the parties take clear and distinct stances on that issue, then the public adjusts their views of the parties based on this issue (Carmines \& Stimson, 1989). Abortion is one of a number of "easy" issues that may have evolved in the second of half of the twentieth century as the parties have taken distinct stances on more issues (for a review see, Carmines \& Wagner, 2006). In the years following Roe, there became no doubt which party supports abortion rights. Hence, it would follow that many Catholics would identify the Republican Party as the pro-life party and leave the Democratic Party.

While arguments surrounding abortion have some appeal, they do not tell the whole story. Even though the Catholic Church's official stance is unequivocally pro-life, the membership is less so. In 2000, almost $40 \%$ of Catholic NES respondents said abortion should always be permitted. Half of George W. Bush's votes among Catholics came from people with views that were sympathetic to abortion rights. If Roe explains Catholic partisanship, then these numbers do not make sense. On top of that, while the official church position on abortion is aligned with the Republican position, it is not at all clear which party would support the church's position on other issues. For example, Gray, Perl, and Bendyna (2006) code a 2004 publication from the U.S. Conference of Catholic Bishops outlining the church's position on political issues. They find that more of the statements were aligned with Democratic positions, rather than Republican positions. ${ }^{3}$

\footnotetext{
${ }^{3}$ Grey, Perl, and Bendyna (2006) code the US Conference of Catholic Bishop's pre-election platform from 2004 called: "Faithful Citizenship: A Catholic Call to Political Responsibility".
} 


\section{Moving Trucks and Partisan Realignment}

Arguments about realignment due to issues or ideology ignore the important contextual changes that have taken place over the past 50 years. A contextual effect is "any effect on individual behavior that arises due to social interaction within the environment" (Huckfeldt \& Sprague, 1993, 298). An individual's neighborhood could affect political attitudes through interactions among neighbors (Segal \& Meyer, 1969; MacKuen \& Brown, 1987). If an individual moved, or if individuals with different ideas moved into the neighborhood, then contextual interactions would change, and therefore, the individual's attitudes might change as well (Brown, 1981). Even if the individuals who moved did not change their opinion of the parties, their children might view the parties differently since they are socialized in a new environment.

The composition of the neighborhoods in which Catholics live has changed over the past fifty years. Following the Second World War, Catholics began moving into the suburbs. Greer (1961) noted this and argued this was part of the upward social movement of Catholics. At the time, Greer did not find any difference in party identification between urban Catholics and suburban Catholics. He did find that the suburban neighborhoods had more heterogeneous networks than Catholics in the cities.

They code 36 separate political positions from this document. Of those 16 are coded as more aligned with Democratic positions and 7 as more aligned with Republican positions. The remaining positions are not clearly associated with either party according to the authors. Among the positions coded as Democratic are "welfare reform that reduces poverty and dependence and not cutting of benefits," “[addressing a] 'culture of violence,' [through] gun safety measures, reasonable restrictions on assault weapons and handguns," and protecting the environment. 
Since Greer's writings, even more Catholics have moved to the suburbs and large numbers of Catholics have moved to the increasingly Republican South. In a later analysis, Penning (1986) emphasized issues and ideology as reason for changes in Catholic partisanship in the 1970s and early 1980s. He did find, however, that place of residence became an increasingly strong predictor of partisanship in the later periods of his analysis.

How would these contextual changes result in partisan change? Social context can affect individual partisanship through a process of autoregressive influence (Huckfeldt, Johnson \& Sprague, 2004; Huckfeldt, Johnson \& Sprague, 2005). With autoregressive influence, every message is weighed against the other messages with consonant messages accepted and dissonant messages rejected. Social network composition can explain why different individuals respond to changes in the information environment in different ways (Sinclair 2012). For example, during a period in which most messages in the news are pro-Republican, individuals in Republican networks will hear similar messages from their friends and family and have stronger Republican views. Individuals in more Democratic networks will be more likely to reject the proRepublican messages because they are not in accord with what they hear in their social networks. Hence, autoregressive influence could explain partisan change, but it could also explain partisan stability when likeminded partisans shielded each other from political tides that do not favor their party.

From the late 1960s into the 1980s, the policy statements of the Democratic Party and the Republican Party underwent several changes (Abramowitz and Saunders 2006). We argue that how individuals responded to these changes was largely dependent on their social context. If a Catholic lived or was born in an area that was favorable to the new Democratic positions, then the individual was likely to identify as a Democrat. Many Catholics, however, now lived in 
areas friendly to the new Republican Party positions. These Catholics living in the South and in the suburbs are the Catholics who either left the Democratic Party or never joined.

To show that changes in context play a large role in explaining the declining association between Catholics and the Democratic Party, we need to show three things: (1) that Catholics lived in the South and suburbs in greater numbers between the 1970s and 1990s; (2) that the relationship between those variables and partisanship changed over the same time period; (3) that aggregate partisanship among Catholics would be very different without those contextual changes. In the following sections, we present this evidence. First, we describe our data showing how context and other factors change over time. Second, we model the relationship between the key variables and partisanship including an interaction effect with year to show how the effect is conditioned on time. Finally, we simulate what Catholic partisanship would have looked like if the contextual changes had never taken place.

\section{Data}

We analyze the competing perspectives of partisan change using data from the American National Election Studies (ANES) between 1972 and 2000. The availability of measures relevant to the theories limits the analysis to these years. Until 1972, the ANES did not ask respondents for their position on abortion or their ideological self-placement. After 2000, the ANES did not include a variable measuring the type of neighborhood in which the respondent lived.

The key dependent variable is partisanship measured via a three category variable indicating if the respondent's party identification is Democratic, Republican, or independent. Scholars have shown that the strength of an individual's attachment to a party can change over time (Fiorina, 1981). It is not clear, however, whether this change is meaningful, or if it is simply 
the result of measurement error (Green \& Palmquist, 1990). Our primary interest is in explaining why fewer Catholics are willing to say they are Democrats, therefore this measure will suffice.

Figure 1 shows the changes in Catholic partisanship over the last fifty years by generation. Some of the changes seen in aggregate partisanship are clearly the result of generational replacement. While previous generations began overwhelmingly Democratic and left the party, the most recent generation did not begin Democratic. In fact, they moved in a Democratic direction during President Clinton's first term only to leave during the second. All three generations reach their low point in 2002, with the two younger generations at approximately forty percent Democratic and the oldest generation at just above $50 \%$ Democratic.

\section{[FIGURE 1 ABOUT HERE]}

We divide our independent variables into three sets: (1) demographics; (2) religiosity and ideology; (3) context. These variables encompass the most likely suspects when trying to understand why the partisanship of group changed over a period of time. In the next few paragraphs, we detail how these variables are coded — each is placed on a 0 to 1 scale. Additionally, Figure 2 and Figure 3 present percentages and means for each of these variables across the decades $(1970 \mathrm{~s}, 1980 \mathrm{~s}$, and 1990s $) .{ }^{4}$ As we investigate possible causes for changes in mass partisanship among Catholics, it is important to look at how Catholics changed over the previous decades. $^{5}$

Demographic Variables

\footnotetext{
${ }^{4}$ Please note that the $y$-axis scale changes in each panel of Figure 2 and Figure 3.

${ }^{5}$ In the appendix, we replicate Figure 2 and Figure 3 for non-Catholics for readers who are interested in a comparison between the groups.
} 
The variable Male is coded 1 if the NES respondent is a male and 0 if the NES respondent is a female. The variables White and Hispanic are coded 1 if the respondent identifies as white or Hispanic, respectively. As Figure 2 shows, males and Hispanics made up larger shares of Catholic identifiers in the 1990s than the 1970s. The increase in Hispanics is accompanied by a decrease in the percentage of Catholic identifiers who are white.

\section{[FIGURE 2 ABOUT HERE]}

Education is coded 0 to 1: 0-the respondent did not graduate high school; .333-the respondent graduated high school; .6667-the respondent attended some college; 1 -the respondent graduated from college. The Income variable measures into which percentile the respondent's family income falls: 0-less than $16^{\text {th }}$ percentile; $.2517^{\text {th }}-33^{\text {rd }}$ percentile; $.534^{\text {th }}-67^{\text {th }}$ percentile; $.7568^{\text {th }}-95^{\text {th }}$ percentile; 1-greater than the $96^{\text {th }}$ percentile.

As you can see, from the 1970 s to the 1990s, the average education increased, but that was not met with an increase in income. In fact, the income percentile in which the typical Catholic fell decreased - although, none of the pairwise comparisons are statistically distinguishable.

\section{Religiosity/Ideology}

In considering how Catholic partisanship has changed, it is important to consider how Catholics have changed: both in terms of their beliefs, but also in terms of their ties to the church. We measure their ties to the church in two ways. First, in line with social identity theory (Tajfel 1978), we examine in-group attachment using feeling thermometer ratings of warmth towards Catholics: the measure Thermometer in the second row of Figure 2. This shows 
no change in feelings towards the church across the decades. ${ }^{6}$ Note that the scandals involving priests sexually abusing children, which may have resulted in Catholics feeling less warm towards their church, were primarily publicized in the media after 2000 . Hence, any potential changes as a result of those scandals would not be reflected in this data.

Alternatively, one could measure attachment to the church by the frequency with which one is involved in church activities. The two panels on the right side of Figure 2's second row show the proportion of individuals who say they attend church weekly, Church Always, and the proportion who say they never attend church, Church Never. The excluded group is those who say they sometimes attend church. This shows a significant change in activity. In the 1970s, $42 \%$ of Catholic identifiers said they attended church always. That number dropped eight percentage points in the 1980s and another two percentage points in the 1990s. The percentage of Catholics saying they never attend church did not change much between the 1970s and the 1980s, but there was a twelve percentage point increase between the 1980s and the 1990s. This could be the result of actual changes in behavior or could reflect a simple willingness to admit to

\footnotetext{
${ }^{6}$ Social identity theory predicts that individuals will show in-group favoritism, out-group derogation, or both (Brewer and Brown 1998). An alternative measure would be to take the difference between the feeling thermometer rating for Catholics and an out-group. For this reason, we also took the difference between the feeling thermometer rating for Catholics and the rating for Protestant. This does change over the years with the difference between the two ratings getting larger. The result in Figure 2 suggests this change is more the result of more outgroup derogation over the decades than any change in in-group favoritism. The other problem with this measure is that the feeling thermometer rating for Protestants was only asked in 1972, 1976 , and 2000.
} 
not attending church. Either way there seems to be a movement away from being practicing Catholics even as people still identified as Catholics.

The first two panels present other indicators of a declining religiosity among Catholic identifiers. The Pro-Life variable is coded 1 if the respondent said that abortion should never be permitted or only if the life of the woman was in danger and 0 otherwise. ${ }^{7}$ As the figure show, the proportion of respondents who gave pro-life answers declined by almost twenty percentage points across the decades.

Bible: Literal combines two different measures. In the 1980s, the measure is coded 1 if the respondent said, "The Bible is God's word and all it says is true", .5 if the respondent said, "The Bible was written by men inspired by God but it contains some human errors", and 0 if the respondent said that the Bible was written by men. In the 1990s, the measure is coded 1 if the respondent said that the Bible should be taken literally, .5 if the respondent said the Bible is the word of God, but should not be taken literally, and 0 if the respondent said the Bible was written

\footnotetext{
${ }^{7}$ The sharp drop seen in 1980 could be the result of a question wording change. After 1980, the ANES added the words "by law" to the question. It is possible that individuals were making a distinction between what the law should allow and their own personal morals. In 1980, they asked both forms of the question and more than three quarters of respondents had the same position on both questions. However, individuals were eight percent less likely to take the prolife position when asked the question in the "by law" form. The ANES also added language about rape and incest that year. One would expect that this change could result in more pro-life respondents because it allows for more situations in which abortions would be allowed and have the respondent still coded as "pro-life".
} 
by men. There is a .06 decline in the mean rating between the 1980s and 1990s again suggesting a declining religiosity among Catholics.

This decline in religiosity is not matched with increased liberalism. The Ideology measure uses the standard ANES seven-point liberal conservative scale and puts it on a $0-1$ scale with 0 indicating extreme conservatism and 1 indicating extreme liberalism. There is a slight move across the decades in the conservative direction, but only the change from the 1970s to the 1990s is statistically distinguishable from zero.

\section{Contextual Measures}

The final panel in Figure 3's first row presents the first contextual measure: County Partisanship. This measure uses county partisanship measured by the Democratic share of the two-party vote in the respondent's county (Gomez, Hansford, and Krause 2007). We construct a z-score for each Catholic respondent by taking the partisanship of the Catholic respondent's county and subtracting the mean county partisanship for all respondents in that year and then divide by the standard deviation of all county partisanships. The positive values for all three decades indicate that the typical Catholic identifier lived and continues to live in a county that was more Democratic than the typical county through the time series. An F-test of the difference of means indicates, however, that the Democratic partisanship in the counties in which Catholics live has declined $(F=5.57 ; p<.02)$.

\section{[FIGURE 3 ABOUT HERE]}

The other results in Figure 3 likely explain the change in the County Partisanship variable. The South graph shows that $14 \%$ of Catholic respondents lived in a Southern state in the 1970s. ${ }^{8}$ The number increased to about $20 \%$ in the 1990 s. Meanwhile, the proportion of

\footnotetext{
${ }^{8}$ South is defined as a respondent who lives in a state that was a member of the Confederacy.
} 
Catholics in urban locations declined while the proportion of Catholics in the suburbs increased.

The South and suburbs saw an increase in Republican affiliation during this same period. ${ }^{9}$

Hence, an increased Catholic presence in these areas would explain the decline in Democratic partisanship in the counties in which Catholics resided.

In the sum, these variables present the puzzle of changing mass-partisanship among Catholics. Catholics become less white, more Hispanic, and less religious from the 1970s to the 1990s. Conventional wisdom would suggest that this should make them more Democratic and not less Democratic. What then explains the decline in the percentage of Catholic Democrats? First, we do expect to see that as the parties became distinct ideologically, the more conservative Catholics were less likely to be Democratic partisans. More importantly, we see in Figure 3 that Catholics moved into the South and the suburbs as these areas became more Republican. We argue these are the individuals who identify with the Republican Party in the 1990s. To test this argument, in the next section, we model Catholic partisanship from 1972 to 2000.

\section{Partisan Change from 1972 to 2000}

${ }^{9}$ Among all ANES respondents, the percentage of Southerners identifying as Democratic dropped 7.9 percentage points from the 1970s to the 1990s. Over that same time period the percentage of Southerners identifying as Republican increased by 11.4 percentage points. Among all ANES respondents, $48.7 \%$ of people living in the suburbs identified as Democratic in the 1990s. That number fell 3.3 percentage points by the 1990s. The more dramatic change came in Republican identification. About $34.7 \%$ of ANES respondents who lived in the suburbs identified as Republican in the 1970s. In the 1990s, 43.6\% of suburban ANES respondents identified as Republican. 
Our argument about why Catholic partisanship changed from the early 1970s to 2000 rests on two factors. First, Catholic identifiers changed in ways demonstrated in Figure 2 and Figure 3. Second, the parties changed causing the relationship between certain variables and partisanship to change. These temporal differences suggest the need for interaction effects. Each of the religiosity (abortion attitude and church attendance), ideological, and contextual variables is interacted with a time marker called Logged Year. We first code 1972 as year 1, 1974 as year 2, and so on until 2000 is year 15 and then we take the natural log of this measure. Logged time is used because the most dramatic changes in the parties happened earlier on in the series.

In addition to adding the Logged Year variable, there is also a change to note in coding of the ideology variables from Figure 2. Ideology is captured by two variables. Liberal is coded 3 if the respondent is extremely liberal, 2 if the respondent is liberal, 1 if the respondent is liberal leaning, and 0 otherwise. Conservative is coded 3 if the respondent is extremely conservative, 2 if the respondent is conservative, 1 if the respondent is conservative leaning, and 0 otherwise. We measure the variable in this way because the appeals Nixon and Reagan made directly to conservative Democrats may have disproportionately affected partisanship of conservatives (Leege et al. 2002). Additionally we include a series of control variables. The coding of these variables is available in the appendix. ${ }^{10}$

\section{[TABLE 1 ABOUT HERE]}

Table 1 presents the results of the multinomial logit model of partisanship from 1972 to 2000 with coefficients for the Republican and independent categories. The coefficients indicate

\footnotetext{
${ }^{10}$ We do not include the feeling thermometer variable from Figure 2 in this analysis because it is not available in all years. We did perform some analyses using that variable. We discuss those analyses in the Further Analyses section.
} 
the relationship between that variable and the probability of being in that category. Positive coefficients indicate that a respondent is more likely to be a Republican or an independent; negative coefficients indicate the respondent is less likely to be in one of those categories.

It is difficult to understand the substantive effects of a multinomial-model with interactions and for this reason, we present Figure 4 and Figure 5. In these figures, we show the probability that a respondent is a Democrat for each of our key variables at the two ends of the time scale. Figure 4 presents the results for our religiosity and ideology variables. Figure 5 presents the results for our contextual variables.

\section{[FIGURE 4 ABOUT HERE]}

\section{Religiosity and Ideology}

The first panel in Figure 4 presents the effect that abortion opinion has on the probability that a respondent is Democratic for 1972 and 2000. The lighter bars are if the respondent is prochoice and the darker bars represent pro-life respondents. At neither time period, are pro-choice and pro-life Catholics statistically distinguishable in the probability that they will identify as a Democrat. The figure does show, however, the effect of the Democratic Party adopting the prochoice position following Roe v. Wade. Pro-life Catholics are 12 percentage points less likely to identify as Democratic in 2000 when compared to 1972 . There is no statistical difference in the probability that a pro-choice Catholic will identify as Democratic over the time periods.

The other variables measuring religiosity are indicators of church attendance: the dummy variables Church Always and Church Never with the excluded category measuring individuals who occasionally attend church. In the figure, increasing church attendance is marked by darker bars. The figures show that church attendance now plays a smaller role in predicting partisanship. In 1972, those who regularly attend church were 15 percentage points more likely 
to report being Democratic compared to those who never attended church. In 2000, there is no discernable difference in partisanship between Catholics who attend church and those who do not attend church.

There are two ways to interpret this result. A social identification perspective (Green et al. 2002) would suggest that, in 1972, active Catholics believed the Democratic Party represented the beliefs of people like them. By 2000, active Catholics no longer held this belief and, as a result, regular church attenders were no longer more likely to identify as Democrats.

Alternatively, a social context argument would suggest that as Catholic churches became less homogeneously Democratic, individuals were less likely to receive messages from their fellow parishioners that were pro-Democratic. Hence, attending church would no longer predict Democratic partisanship. Further, individuals may no longer believe the Democratic Party represents Catholics because of a contextual affect. We are unable to distinguish between the two mechanisms, but adjudicating between the two interpretations is beyond the goals of this paper.

The final panel of Figure 4 examines ideology. There is some evidence of the partisan sorting that took place after the parties clarified their ideological positions (Abramowitz and Saunders 2006; Fiorina 2006). In 1972, there was a 52.5 percentage point difference in the probability that an extreme liberal would be a Democrat compared to an extreme conservative. By 2000, the effect of ideology had grown to 76.7 percentage points. We must note, however, 
that the confidence intervals on these predictions do overlap making it difficult to say

conclusively that ideology plays a larger role in determining partisanship. ${ }^{11}$

\section{Contextual Variables}

[FIGURE 5 ABOUT HERE]

Figure 5 displays how the relationship between contextual variables and partisanship has changed from 1972 to 2000 . The first panel looks at the South variable. Region is a strong predictor of partisanship throughout the series, but the effect has reversed its direction. In 1972, southern Catholics were more likely to be Democrats than non-southern Catholics, but, by 2000, they were less likely to identify as Democrats. This shifting of southern partisanship has been well documented, but it is an underappreciated cause of changes in Catholic partisanship.

What has received less scholarly attention is how the effect of urban context on partisanship has changed. In 1972, there are no statistically distinguishable effects for living in an urban, suburban, or rural environment. In 2000, there is a sharp divide between people who live in cities and those who live in the suburbs. There is a $60 \%$ probability an urban Catholic will identify as a Democrat compared to a $50 \%$ probability that a suburban Catholic will do so. This change is largely due to the increasingly Republican suburbs. The figure does not show this, but the probability of being a Republican in the suburbs doubled from 1972 to 2000 .

\section{The Cumulative Effect of Changes}

\footnotetext{
${ }^{11}$ We ran the same model on non-Catholics and in that specification ideology clearly plays a larger role in determining partisanship in later years with larger effects for the ideology variables in 2000 .
} 
In Figure 2 and Figure 3, we showed how Catholics changed on key variables from the 1970s to the 1990s. In the previous section, we modeled how the relationship between those key variables and partisanship changed over the same time period. If we are looking at changes in mass partisanship, however, we need to take both factors into account simultaneously. For example, imagine more Catholics had a value of 1 on some dummy variable $X$ at the end of a time series than they did at the beginning of the time series. If that $X$ variable is always a positive predictor of Democratic partisanship, then we could say that change led to increasing numbers of Democrats among Catholics. If $X$ became less associated with partisanship, then the increase in the percentage of Catholics with a 1 on $X$ is potentially less relevant to explaining changes in mass partisanship.

For this reason, we perform a series of simulations to examine counterfactuals. These simulations are similar in spirit to those run to understand the effects of knowledge on vote choice and policy opinions (e.g., Bartels 1996; Althaus 1998; Ryan 2010). They examine hypothetical partisanship in the 1990s keeping all the variables and relationships at their 1990 levels except for key sets of variables. This allows us to estimate what partisanship would have looked like if some of the changes that took place over time had not occurred. For example, what if the Democratic Party did not identify as the pro-choice party? What if fewer Catholics had moved to the suburbs?

We carry out the simulation using the following steps.

- We create fifty datasets that are identical to the ANES cumulative file for Catholics in the 1990s.

- For a set of variables—religiosity, ideology, or context—we replace respondent's values on those variables. We randomly assign values to respondents with probabilities 
matching the probabilities of those values in the 1970s. Note we do this for each set of key variables separately.

- We change the coefficient of the interaction effects on those key variables to zero. This means that the relationship between the variables and partisanship is the same as it was in 1972-year 0 for the Logged Year variables. All other interaction effects are unchanged.

- We predict the probability that each respondent would be Democratic recording the mean probability for each of the 50 datasets that we created.

What this allows us to do is determine what Catholic partisanship would have looked like a) if the changes in religiosity had not taken place, b) if the ideological changes had not taken place, and c) if the contextual changes had not taken place. The largest difference between actual 1990s partisanship and simulated 1990s should suggest the variables that had the largest effect on mass partisanship among Catholics.

\section{[FIGURE 6 ABOUT HERE]}

The results of the simulation are shown in Figure 6. The dotted vertical line on the left shows the actual mean probability of Democratic partisanship in the 1990s. To the right are density plots of the mean probabilities from the simulations on the 50 data sets. ${ }^{12}$ The Figure shows that without the changes in ideology_-both changes in the ideological positions of Catholics and the partisan sorting that took place - the average Catholic would be about 2 percentage points more likely to identify as a Democrat. This small effect of ideological changes on mass partisanship should not be that surprising. While conservatives became less

\footnotetext{
${ }^{12}$ Please note, there are 50 data sets for each of the three sets of variables (religiosity, ideology, context). Hence, we created 150 data sets total for the simulations.
} 
Democratic, liberals became more Democratic; hence, the actual net effect on macropartisanship is small.

The effect of religiosity is also small; it is about the same as ideology, with the mean from the simulations about half a percentage point higher. With all the attention paid to abortion and declining religiosity, why did this not have a larger effect? On the one hand, the changing Democratic positions did severe a bond with a strong voting bloc: active, observant Catholics. On the other hand, this is a group that shrank in numbers over the next twenty years. Hence, if we are trying to understand the changes in mass partisanship among Catholics, the Democratic Party siding with the pro-choice movement had an effect, but not as large as one would think given the attention the issue receives.

The differences between the simulated results and the actual vote share are the largest for the contextual changes. According to the simulation, $62.5 \%$ of Catholics would identify as Democratic if the contextual changes had not taken place. This is not simply the result of Catholics moving into the South and the suburbs in greater numbers. It is the combined effect of Catholics moving into those areas while those areas became increasingly Republican.

This suggests a larger point about the mass partisanship of all groups. In some instances, party efforts to specifically target groups have a large effect-for example, the partisan changes around race in the 1960s (Carmines and Stimson 1989; Huckfeldt and Kohfield 1989). In other instances, groups make up a greater or lesser part of a party for reasons beyond policy positions alone. For example, Claasseen and Povtak (2010) show that the Christian Right became a major player in the Republican Party less because of mobilization and more because of demographic changes. 
We are not arguing that policy does not matter at all. Our results suggest that the policies that Democrats took that cost them Southerners also cost them some share of the Catholic vote as well. We are simply arguing that it is a mistake to argue that any particular policy or rhetorical appeal explains partisan change among a large group. We use the word "Catholic" to group 25\% of American public together. Any group that large will be diverse in many ways. Hence, the factors that explain changes in voting patterns among that group will also be complex and many of the factors that shape this group will also affect the larger public.

\section{Further Analyses}

Any analysis attempting to explain mass partisan change over a thirty year period should be greeted with caution. Data are rarely (if ever) available to test mechanisms. The measures used are largely proxy measures and measures for alternative explanations may not be available. These concerns would apply to the current analysis as well.

For example, we can show that where Catholics live plays a large role in explaining their partisanship. We cannot show exactly how the contextual effect occurs. We suspect it occurs through a process of autoregressive influence (Huckfeldt, Johnson, and Sprague 2004). Without either an experiment (e.g., Huckfeldt, Pietryka, and Reilly 2014; Ryan 2013) or close monitoring of individual conversations (e.g., Walsh 2004), we are unable to measure the different messages that are sent in different contexts. Further, even with all the controls, selection effects could drive the results - that is, individuals may choose to live in a particular context that better represents their partisan beliefs and thus the correlation between individual partisanship and political context is spurious (Achen and Shively 1995). 
As a robustness check, we conduct another analysis using Catholic respondents in the 2000-2002 NES Panel data. This does not directly test our argument about the mass partisan change over the past 30 years, but it does provide evidence for the mechanism that we suggest explains the contextual results. Following the attacks of September $11^{\text {th }}$, this time period saw an increase in Republican identification no doubt caused in part by the spike in President Bush's approval (MacKuen, Erikson, Stimson 1989). The dataset also offers a measure of each respondent's ego network in 2000 (for a discussion of ego network data see Klofstad et al. 2009). Hence, the model includes a measure of the respondent's network prior to any change that might have caused the respondent to identify with a different political party in $2002 .^{13}$

Between 2002 and 2000, 19.7\% of Catholics reported changing parties. Twice as many switched from the Democratic Party to the Republican Party than vice versa. It is unclear if these changes are true changes in partisanship or simply the result of individuals wanting to say they identify with the party of the popular President Bush. We model these changes using a structural equation model. A full discussion of the structural equation model is available in the appendix.

${ }^{13}$ This does not necessarily demonstrate causality (Fowler et al. 2011). For example, it is possible that those who are in disagreeable networks selected into those networks in part because they were most likely to change. Further, the partisanship of the social network is measured using the respondents' perceptions of their network which could lead to error. Huckfeldt, Sprague and Levine (2000) demonstrate that perceptions of partisanship are typically correct. Further, as Sinclair points out in Fowler et al. (2011), the respondent's perception of his or her discussion partners is the key variable since the respondent is reacting to his or her interactions with the social network and not the actual party attachments of the social network. 
The results show that an individual's social network in 2000 affects their partisanship in 2002. Moving from a network that was homogeneous in its support for Gore to a network that was homogeneous in its support for Bush would move an individual about 0.77 points on the 7 point partisanship scale. ${ }^{14}$ This result controls for the individual's partisanship in 2000 and is over and above the affect the network had on the individual's 2000 partisanship. Again, an analysis of individual level partisan change from 2000-2002 does not explain mass partisan change from the 1970 s to the 1990s. This analysis does suggest, however, that Catholic partisanship does respond to non-religious political events through the influence of social networks.

While we emphasize the importance of social context in explaining partisan change, we have paid less attention to the role of social identification theory. The social identification theory centers on groups. It argues individuals identify with parties because the groups of which they are members are associated with those parties (Green, Palmquist \& Schickler, 2002). For example, proponents of social identification would argue that members of minority groups tend to be more Democratic because of the associations between the Democratic Party and minority groups. If the association between a group and a party is severed-like the association between white Southerners and the Democratic Party - then the tie that a member of that group has to the party will also eventually be severed.

Measurement issues make it difficult for us to directly address this argument as the existing data do not provide us with a good measure of how strongly Catholics identify with their

\footnotetext{
${ }^{14}$ We conducted the same analysis using all ANES respondents. The effect in that analysis is larger - about 1 point on the scale — with a statistically significant effect for both the Gore Discussants and Bush Discussant variables. Those results are also available in the appendix.
} 
Catholicism. The measures of religiosity are potentially proxies for strength of Catholic identity. Hence, it is possible that the partisan change we attribute to disagreement over policy is really caused by a belief that Democrats do not care about Catholics in a way that they used to care about Catholics.

We attempt to more directly measure Catholic identity using the feeling thermometer ratings of warmth towards Catholics. As we showed in Figure 3, the average feeling thermometer rating did not change from the 1970s to the 1990s. This does not necessarily mean that this variable cannot explain the mass partisan change. All that would be required is that the relationship between the variable and partisanship to change over the time period. Hence, we would need a statistically significant interaction between thermometer and the Logged Year indicator to find support for a social identification hypothesis using the feeling thermometer rating.

We ran several models and none resulted in a statistically significant interaction effect. ${ }^{15}$ Post-estimation analysis suggests the marginal effect of the feeling thermometer is consistent throughout the years. Further, the feeling thermometer rating is a poor predictor of Democratic partisanship at every time point from 1972-2000. The bivariate relationship between the feeling thermometer rating and partisanship is not statistically significant. Again, this result does not mean that social identification theory does not explain some proportion of the partisans change among Catholics, but we cannot distinguish between a clear social identification effect and a religiosity effect using the available data.

\section{Conclusion}

${ }^{15}$ These models are available in the appendix. 
When attempting to understand the mass partisan change of a demographic group, it is tempting to paint the group as a caricature or to believe the voices of the most vocal represent the viewpoints of the entire group. For this reason, one might assume that Catholics are no longer a strong Democratic voting bloc because of the Democratic Party's adoption of a pro-choice policy stance following Roe v. Wade. U.S. Catholic Bishops clearly are unhappy with the Democratic Party's abortion policy and Republican candidates have seen abortion and reproductive issues more generally as a potential area for making appeals to Catholics.

Our analysis shows that abortion policy likely played a role in the partisan change experienced by Catholics. We also show that partisan sorting explains some of the partisan change among Catholics as it does among voters more generally. However, the effect of both of these factors plays a much smaller role than the effect of context. We show that Catholics stopped being a solid Democratic voting bloc in the second half of the $20^{\text {th }}$ century largely because they no longer receive homogeneously pro-Democratic messages in their communities. Older Catholics have left the Democratic Party in recent years with most of those defections coming among Catholics who live in the South or the suburbs. In the 1980s and 1990s, these contexts became increasingly Republican. So, the messages received by Catholics living here became increasingly Republican and some were persuaded to leave the Democratic Party and younger generations never even identified as Democrats.

All of the most prominent theories of partisan change - issue evolution, social identification, and ideological realignment - place new information at the center of their models. All of these theories are agnostic, however, about how this new information is communicated. If most Americans are uninterested and uninformed, it seems unlikely that they would learn party positions on issues or whether parties are ignoring certain groups or what elites are saying. If 
individuals are not going to receive the messages on their own, they are going to come from the people around them that are paying attention (Lazarsfeld, Berelson \& Gaudet, 1948; Katz, 1957).

This is why this contextual model explains the change so well. Instead of concentrating on the specific content of particular messages, it centers on which individuals are most likely to hear and accept the new messages - this is determined, in part, by an individual's social surrounding (Sinclair 2012). What matters is the direction of the message - pro-Democratic or pro-Republican - not the issue the message addresses. For Catholics, the anti-Democratic and pro-Republican messages were heard most clearly in the increasingly Republican South and suburbs. Individuals may have been able to ignore them at first, but, as more and more of their discussions about politics had an anti-Democratic tone, those messages gained credibility. 


\section{References}

Abramowitz, A. I. \& K. L. Saunders. (2006). Exploring the Bases of Partisanship in the American Electorate: Social Identity vs. Ideology. Political Research Quarterly, 59(2): 175187.

Achen, C. H. and W. P. Shively. (1995). Cross-Level Inference. Chicago: University of Chicago Press.

Adams, G. D. (1997). Abortion: Evidence of an Issue Evolution. American Journal of Political Science, 41(3): 718-737.

Althaus, S.L. 1998. Information Effects in Collective Preferences. American Political Science Review, 92(3): 545-558.

Barreto, M. A. and F. I. Pedraza. 2009. The Renewal and Persistence of Group Identification in American Politics. Electoral Studies, 28(4): 595-605.

Bartels, L.M. 1996. Uninformed Votes: Information Effects in Presidential Elections. American Journal of Political Science, 40(1)194-230.

Berelson, B. R., P. F. Lazarsfeld \& W. N. McPhee. (1954). Voting: A Study of Opinion Formation in a Presidential Campaign. Chicago: University of Chicago Press.

Brewer, M. B., \& Brown, R. J. (1998). Intergroup relations. In D. T. Gilbert et al. (Eds.), The handbook of social psychology (Vol. 2, 4th ed.)New York: McGraw-Hill. 554-594.

Brown, T. A. (1981). On Contextual Change and Partisan Attributes. British Journal of Political Science, 11(4): 427-447.

Campbell, A., P. E. Converse, W. E. Miller \& D. E. Stokes. (1960). The American Voter. Chicago: University of Chicago Press. 
Carmines, E. G., and J. A. Stimson. (1980). “The Two Faces of Issue Voting.” American Political Science Review 74(1): 78-91.

Carmines, E. G. \& J. A. Stimson. (1989). Issue Evolution: Race and the Transformation of American Politics. Princeton, NJ: Princeton University Press.

Carmines, E. G. \& M. W. Wagner. (2006). Political Issues and Party Alignments: Assessing the Issue Evolution Perspective. Annual Review of Political Science, 9: 67-81.

Claasseen, R.L. and A. Povtak. (2010). The Christian Right Thesis: Explaining Longitudinal Change in Participation among Evangelical Christians. The Journal of Politics, 72(1): 2-15. Fiorina, M. P. (1981). Retrospective Voting in American National Elections. New Haven, CT: Yale University Press.

Fiorina, M. P. (2006). Culture War? The Myth of a Polarized America $2^{\text {nd }}$ Edition. New York: Longman.

Fowler, J. H., M. T. Heaney, D. W. Nickerson, J. F. Padgett, and B. Sinclair. 2011. Causality in Political Networks. American Politics Research, 39(2): 437-480.

Gomez, B. T., T. G. Hansford, and G. A. Krause. (2007). The Republicans Should Pray for Rain: Weather, Turnout, and Voting in U.S. Presidential Elections. The Journal of Politics, 69(3): 649-663.

Gray, M. M., P. M. Perl, \& M. E. Bendyna. (2006). Camelot Only Comes by Once? John F. Kerry and the Catholic Vote. Presidential Studies Quarterly, 36(2): 203-222.

Green, D. P. \& B. Palmquist. (1990). Of Artifacts and Partisan Instability. American Journal of Political Science, 34(3): 872-902.

Green, D., B. Palmquist and E. Schickler. (2002). Partisan Hearts and Minds: Political Parties and the Social Identities of Voters. New Haven, CT: Yale University Press. 
Greer, S. (1961). Catholic Voters and the Democratic Party. The Public Opinion Quarterly, 25(4): 611-625.

Hetherington, M. (2002). "Resurgent Mass Partisanship: The Role of Elite Polarization." American Political Science Review, 95(3) 619-631.

Hillygus, D. S. \& T. G. Shields. 2008. The Persuadable Voter: Wedge Issues in Presidential Campaigns. Princeton, NJ: Princeton University Press.

Huckfeldt, R. and C. W. Kohfield. (1989). Race and the Decline of Class in American Politics. Urbana: University of Illinois Press.

Huckfeldt, R., P. E. Johnson \& J. Sprague. (2004). Political Disagreement: The Survival of Diverse Opinions within Communication Networks. New York: Cambridge University Press.

Huckfeldt, R., P. E. Johnson \& J. Sprague. (2005). Individuals, Dyads, and Networks: Autoregressive Patterns of Political Influence. In A. Zuckerman (ed.), The Social Logic of Politics. Philadelphia: Temple University Press.

Huckfeldt, R., M. T. Pietryka, and J. Reilly. (2014). “Noise, Bias, and Expertise in Political Communication Networks." Social Networks, 36(1):110-121.

Huckfeldt, R. \& J. Sprague. (1993). Citizens, Contexts, and Politics. In A. Finifter (Ed.), Political Science: State of the Discipline II. Washington, DC: American Political Science Association.

Huckfeldt, R., J. Sprague and J. Levine. (2000). The dynamics of collective deliberation in the 1996 election: Campaign effects on accessibility, certainty, and accuracy. American Political Science Review, 94() 641-651. 
Jelen, T. G., and C. Wilcox. (2003). Causes and Consequences of Public Attitudes toward Abortion: A Review and Research Agenda. Political Research Quarterly, 56 (4): 489-500.

Katz, E. (1957). The Two Step Flow of Communication: An Up-to-Date Report on an Hypothesis. Public Opinion Quarterly, 21(1): 67-81.

Key, V.O. (1955). A Theory of Critical Elections. The Journal of Politics, 17(1): 3-18.

Klofstad, C. A., S. McClurg, and M. Rolfe. 2009. Measurement of Political Discussion Networks: A Comparison of Two 'Name Generator' Procedures. Public Opinion Quarterly, 73: 462-483.

Lazarsfeld, P. F., B. Berelson \& H. Gaudet. (1948). The People's Choice: How a Voter Makes Up His Mind in a Presidential Campaign. New York: Columbia University Press.

Leege, D. C., K. D. Wald, B. S. Krueger \& P. D. Mueller. (2002). The Politics of Cultural Differences: Social Change and Voter Mobilization Strategies in the Post-New Deal Period. Princeton, NJ: Princeton University Press.

MacKuen, M. \& C. Brown. (1987). Political Context and Attitude Change. American Political Science Review, 81(2): 471-490.

MacKuen, M. B., R. S. Erikson, and J. A. Stimson. (1989). Macropartisan. American Political Science Review, 83(4): 1125-1142.

McAvoy, T. (1942). The Catholic Church in the United States between Two Wars. The Review of Politics, 4(4):409-431.

McCarty, N. K. Poole, and H. Rosenthal. 2006. Polarized America: The Dance of Ideology and Unequal Riches. Cambridge, MA: MIT Press.

McDaniel, E. L. and C. G. Ellison. (2008). God's Party? Race, Religion, and Partisanship over Time. Political Research Quarterly, 61(2):180-191. 
Milazzo, C., J. Adams, and J. Green. (2012). Are Voter Decision Rules Endogenous to Parties' Policy Strategies? A Model with Applications to Elite Depolarization in Post-Thatcher Britain. The Journal of Politics, 74(1): 262-276.

Penning, J. M. (1986). Changing Partisanship and Issue Stands Among American Catholics. Sociological Analysis, 47(1): 29-49.

Ryan, J. B. (2010). The Effects of Network Expertise and Biases on Vote Choice. Political Communication, 27(1): 44-58.

Ryan, J. B. (2013). An Experimental Study of Persuasive Social Communication. Political Communication, 30(1): 100-116.

Segal, D. R. \& M. W. Meyer. (1969). The Social Context of Political Partisanship. In M. Dogan \& S. Rokkan (eds.), Quantitative Ecological Analysis in the Social Sciences. Boston: MIT Press.

Sinclair, B. (2012). The Social Citizen: Peer Networks and Political Behavior. Chicago: University of Chicago Press.

Stimson, J. A. (2004). Tides of Consent: How Public Opinion Shapes American Politics. New York: Cambridge University Press.

Tajfel, H. (1978) The achievement of group differentiation. In H. Tajfel (Ed.), Differentiation between social groups: Studies in the social psychology of intergroup relations. London: Academic Press. 77-98.

Walsh, K.C. (2004). Talking About Politics: Informal Groups and Social Identity in American Life. 
Table 1. Multinomial Logit Model of the Partisanship of Catholic NES Respondents, 1972-2000

\begin{tabular}{|c|c|c|c|c|}
\hline & \multicolumn{2}{|c|}{ Republican } & \multicolumn{2}{|c|}{ Independent } \\
\hline & Coef. & Z-Value & Coef. & Z-Value \\
\hline Pro Life & -0.312 & -2.50 & -0.289 & -2.21 \\
\hline Church Always & 0.084 & 0.43 & -0.677 & -1.76 \\
\hline Church Never & 0.651 & 2.53 & 0.022 & 0.08 \\
\hline Liberal & -0.950 & -4.94 & -0.043 & -0.21 \\
\hline Conservative & 0.658 & 6.70 & -0.071 & -0.24 \\
\hline South & -1.337 & -3.46 & -0.263 & -0.95 \\
\hline Suburb & -0.398 & -1.57 & -0.359 & -2.46 \\
\hline Rural & -0.092 & -0.49 & -0.451 & -1.97 \\
\hline Logged Year & -0.118 & -1.36 & -0.579 & -3.31 \\
\hline Pro Life*Year & 0.191 & 2.04 & 0.105 & 1.23 \\
\hline Church Always*Year & -0.138 & -1.12 & 0.323 & 1.66 \\
\hline Church Never*Year & -0.290 & -2.75 & 0.089 & 0.60 \\
\hline Liberal*Year & 0.119 & 1.04 & -0.271 & -2.59 \\
\hline Conservative*Year & 0.047 & 0.67 & 0.080 & 0.69 \\
\hline South*Year & 0.704 & 3.83 & 0.209 & 1.56 \\
\hline Suburb*Year & 0.295 & 2.57 & 0.254 & 2.82 \\
\hline Rural*Year & 0.017 & 0.14 & 0.305 & 3.03 \\
\hline Birth Year & 0.011 & 2.64 & 0.029 & 3.88 \\
\hline Male & 0.352 & 5.54 & 0.458 & 3.04 \\
\hline White & -0.043 & -0.16 & -0.309 & -0.64 \\
\hline Hispanic & -0.787 & -2.49 & -0.677 & -1.44 \\
\hline Black & -1.276 & -3.04 & -0.572 & -0.90 \\
\hline Income & 0.952 & 3.89 & 0.080 & 0.28 \\
\hline Education & 0.615 & 5.45 & -0.336 & -1.77 \\
\hline Union & -0.661 & -8.37 & -0.258 & -1.88 \\
\hline Working & -0.140 & -0.72 & -0.502 & -2.18 \\
\hline Retired & 0.136 & 0.75 & 0.090 & 0.30 \\
\hline Homemaker & 0.198 & 0.92 & -0.323 & -1.10 \\
\hline Student & -0.241 & -0.72 & -0.852 & -2.63 \\
\hline Home Owner & -0.089 & -1.03 & 0.102 & 0.97 \\
\hline Married & 0.044 & 0.35 & 0.322 & 2.35 \\
\hline Divorced & 0.103 & 0.50 & 0.104 & 0.51 \\
\hline Widow & 0.066 & 0.28 & 0.486 & 1.32 \\
\hline Constant & -22.040 & -2.79 & -56.940 & -3.85 \\
\hline & $\mathrm{N}=4,029$ & & A.I.C. $=$ & .974 \\
\hline
\end{tabular}

Notes. Standard errors corrected for clustering on survey year and sampling weights are used. Bold and italicized variables are statistically significant at the .05 level in a one-tailed test. Democrat is the excluded category. 
Figure 1. Changes in Democratic Partisanship of Catholic NES Respondents By Generation, 1960-2004.

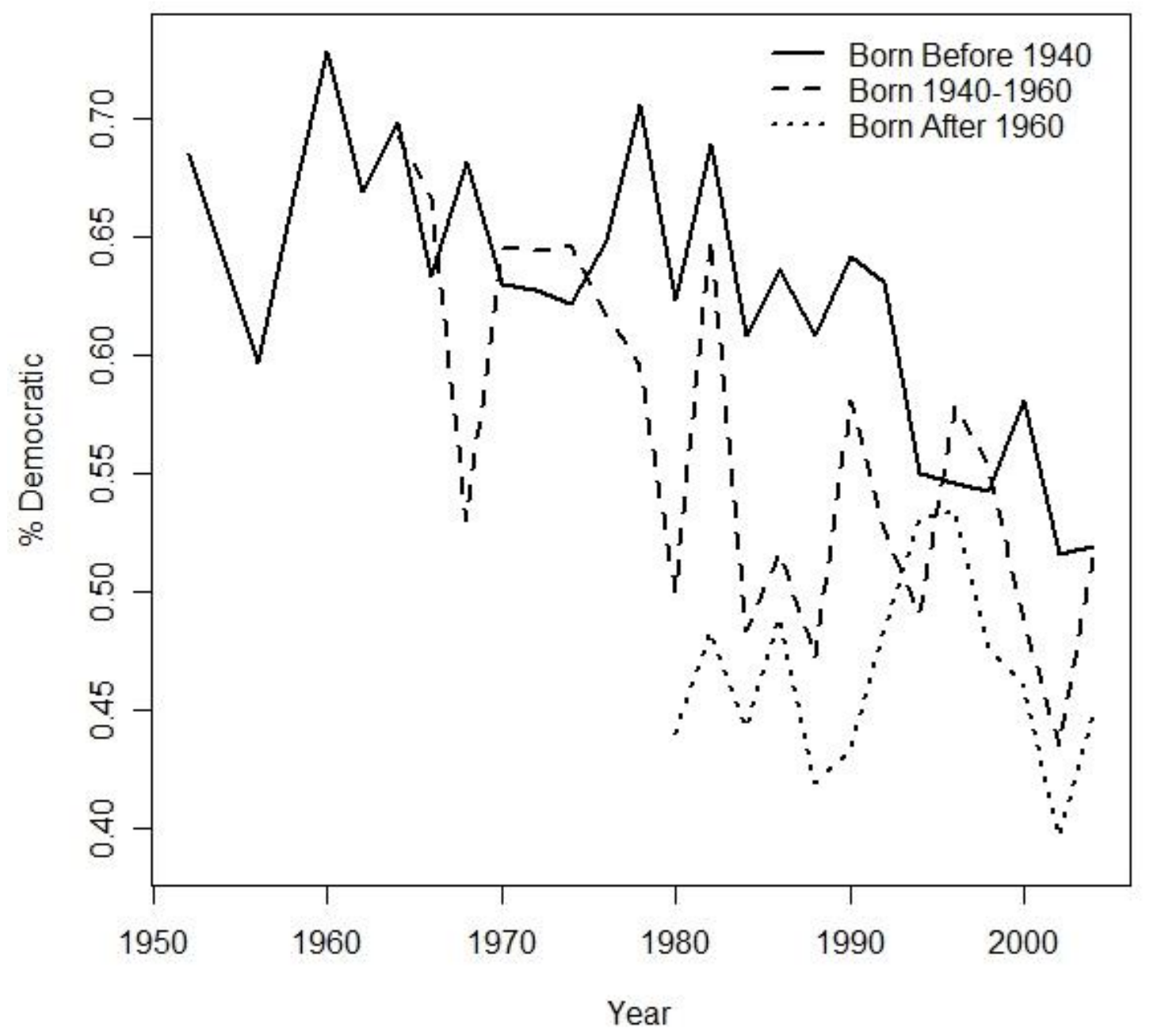


Figure 2. Means of demographic, religiosity, and ideology variables by decade.

A. Demographics
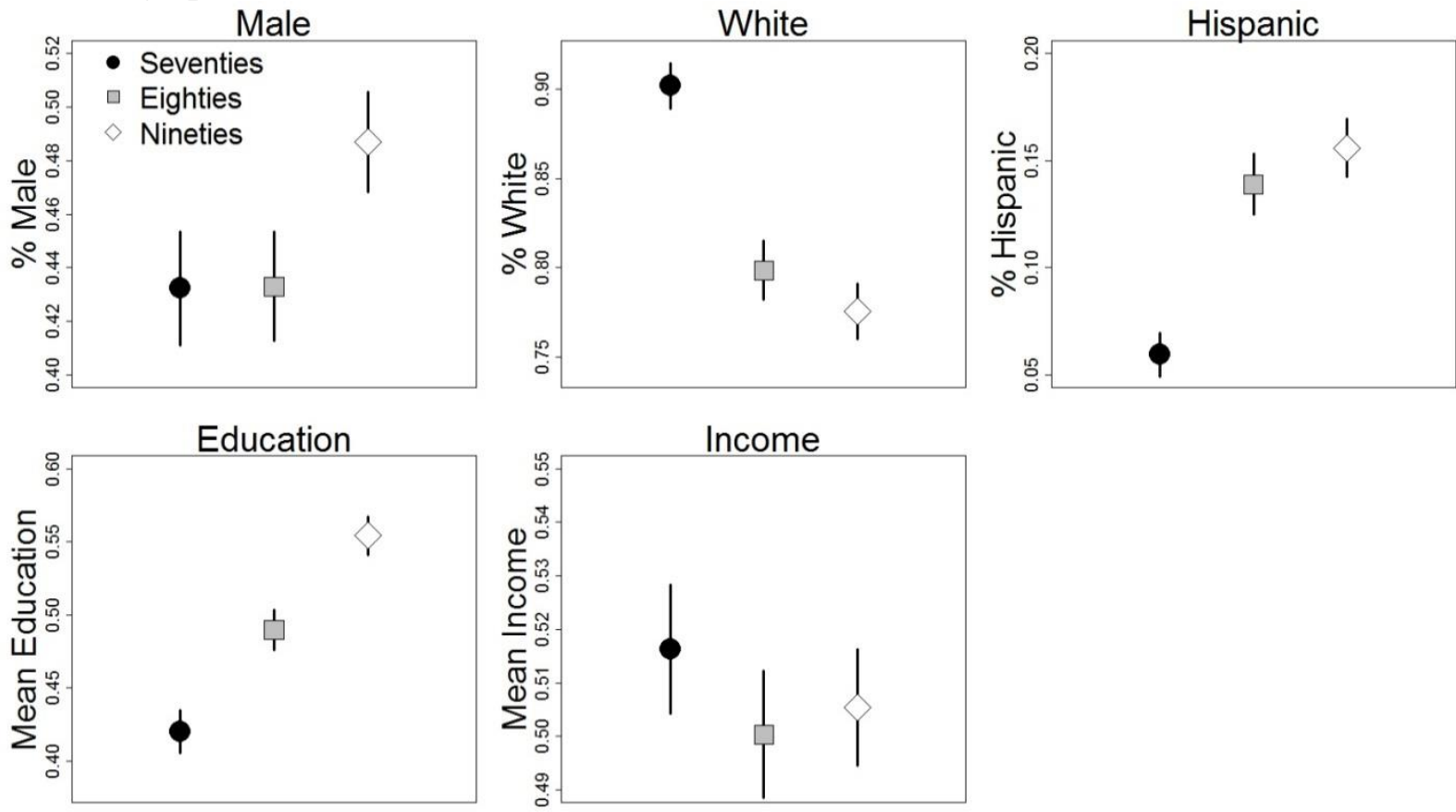

B. Religiosity/Ideology
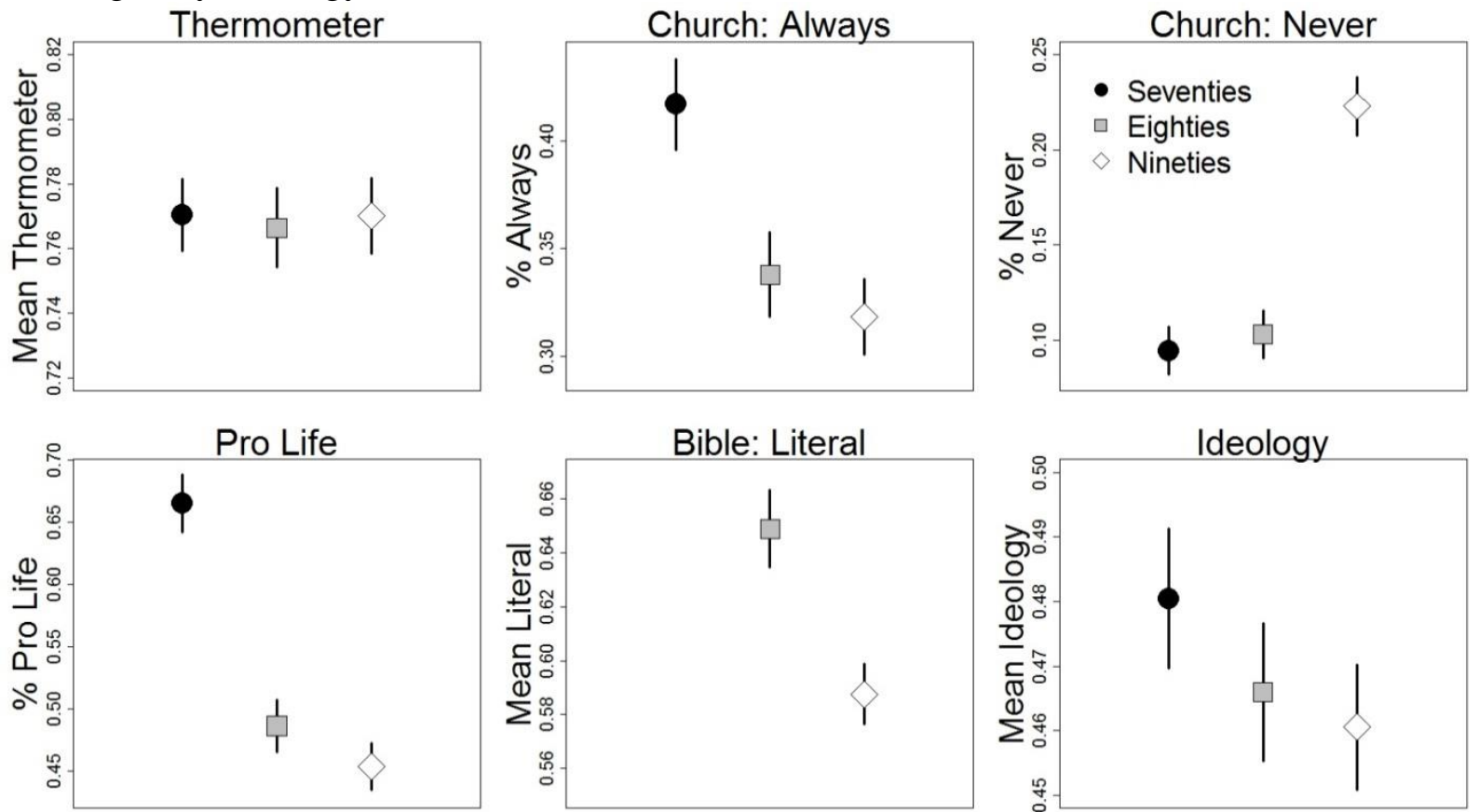

Error bars represent $95 \%$ confidence intervals. 
Figure 3. Means of contextual variables by decade.
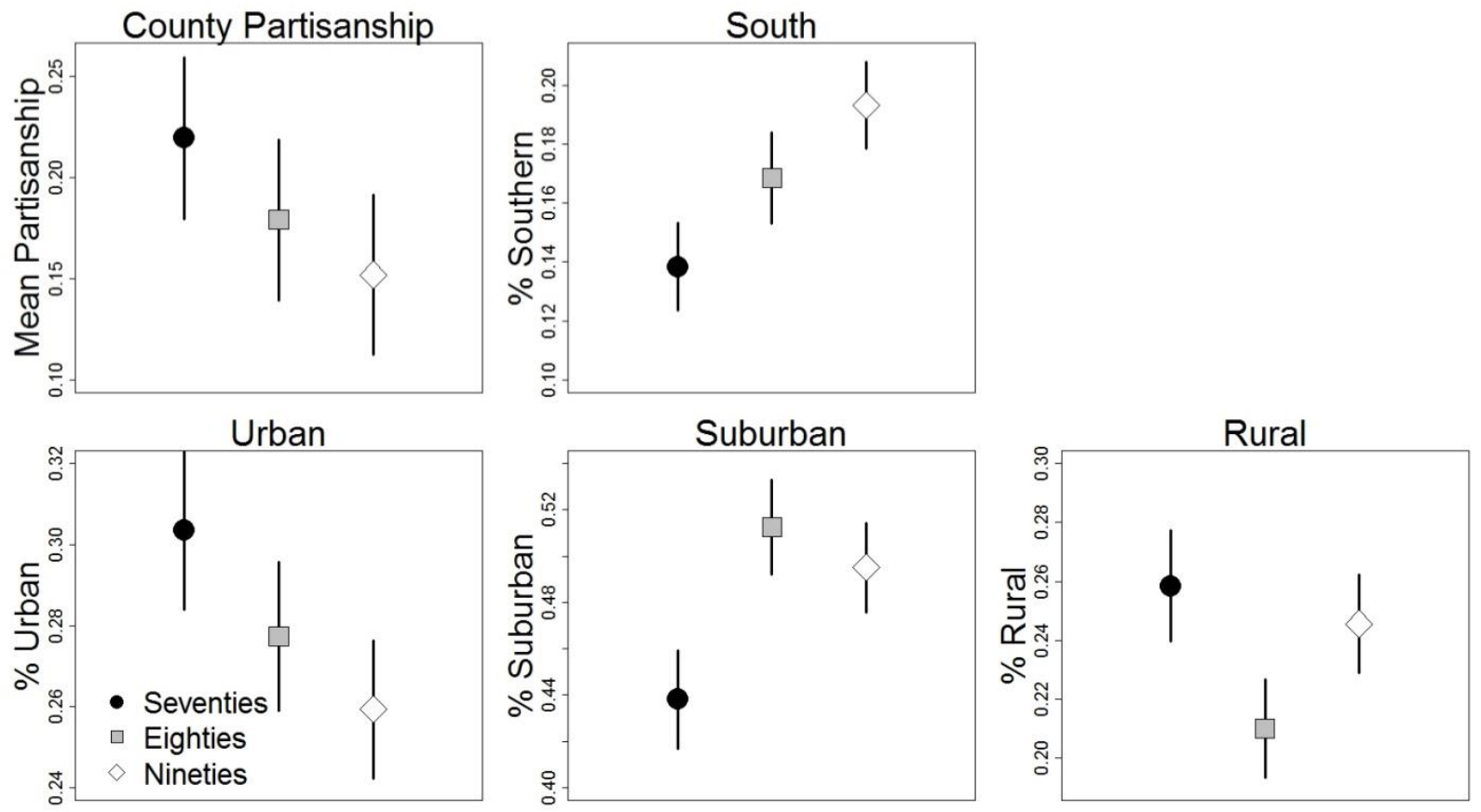

Error bars represent $95 \%$ confidence intervals. 
Figure 4. Predicted probabilities that Catholics identify as Democrats for religiosity and ideology variables.
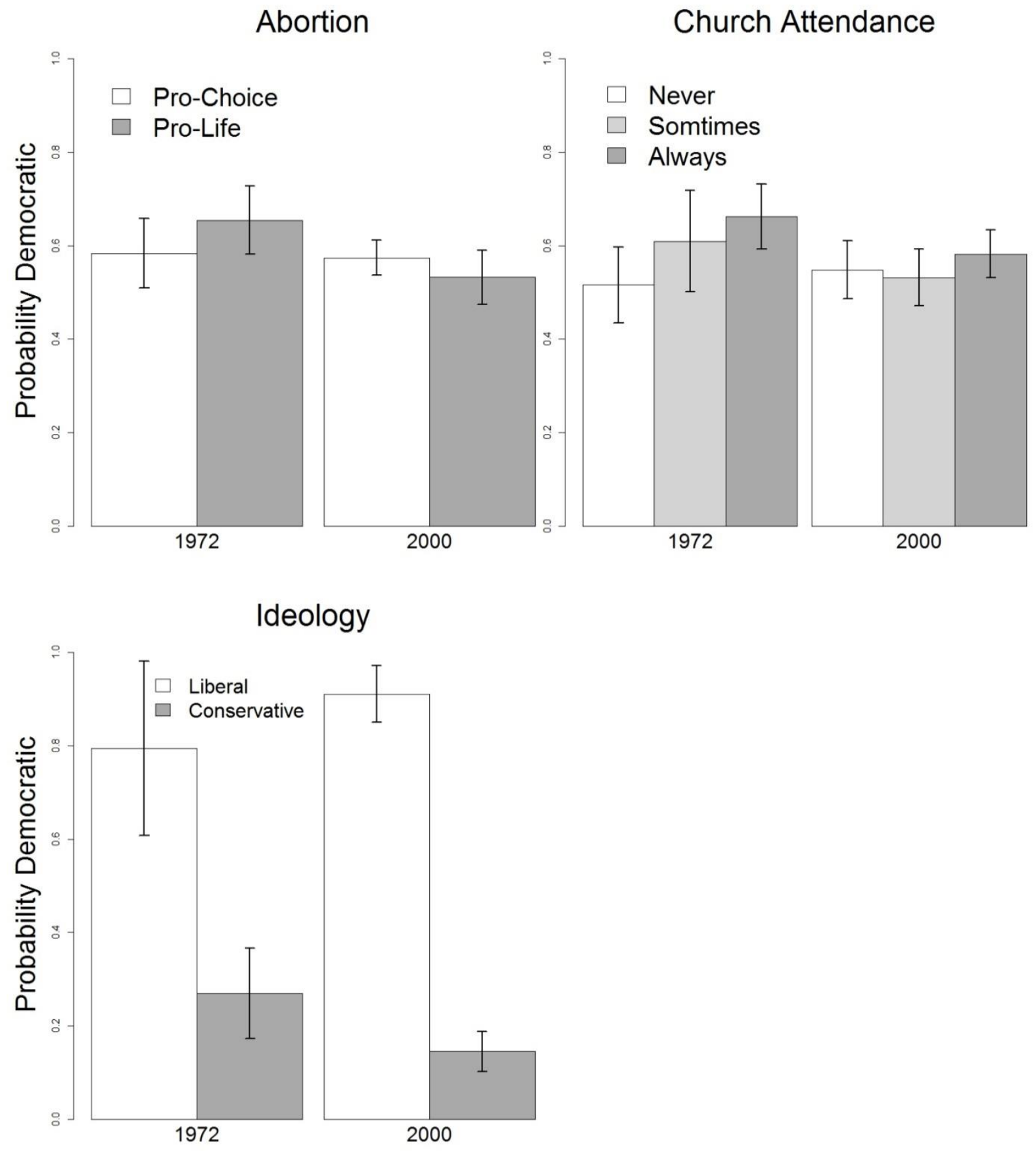

Error bars represent 95\% confidence intervals. Probabilities calculated using estimates from model in Table 1. 
Figure 5. Predicted probabilities that Catholics identify as Democrats for contextual variables.

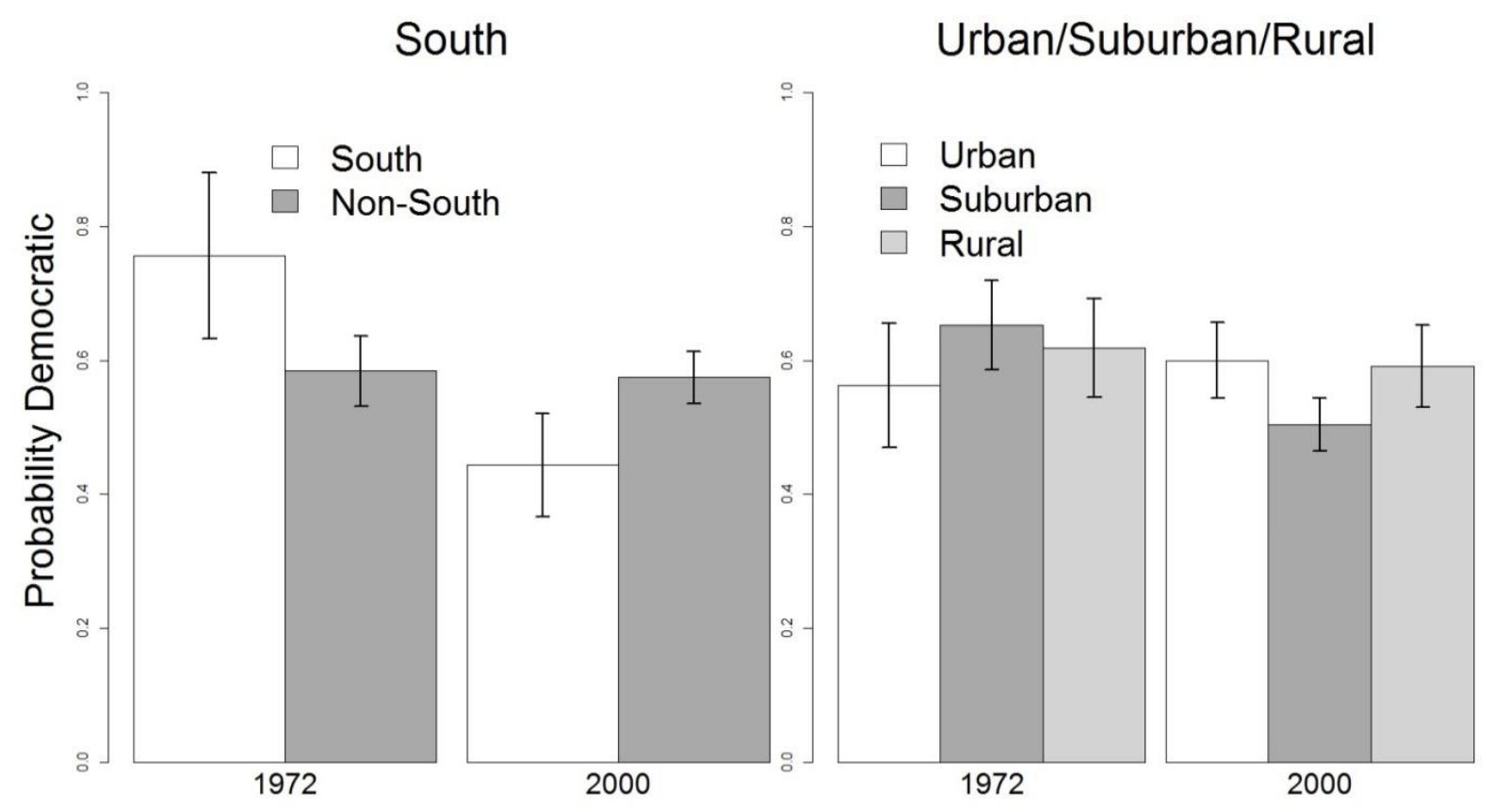

Error bars represent $95 \%$ confidence intervals. Probabilities calculated using estimates from model in Table 1. 
Figure 6. Simulated partisanship if changes from 1970s-1990s had not taken place. Figure shows densities of means from fifty simulations.

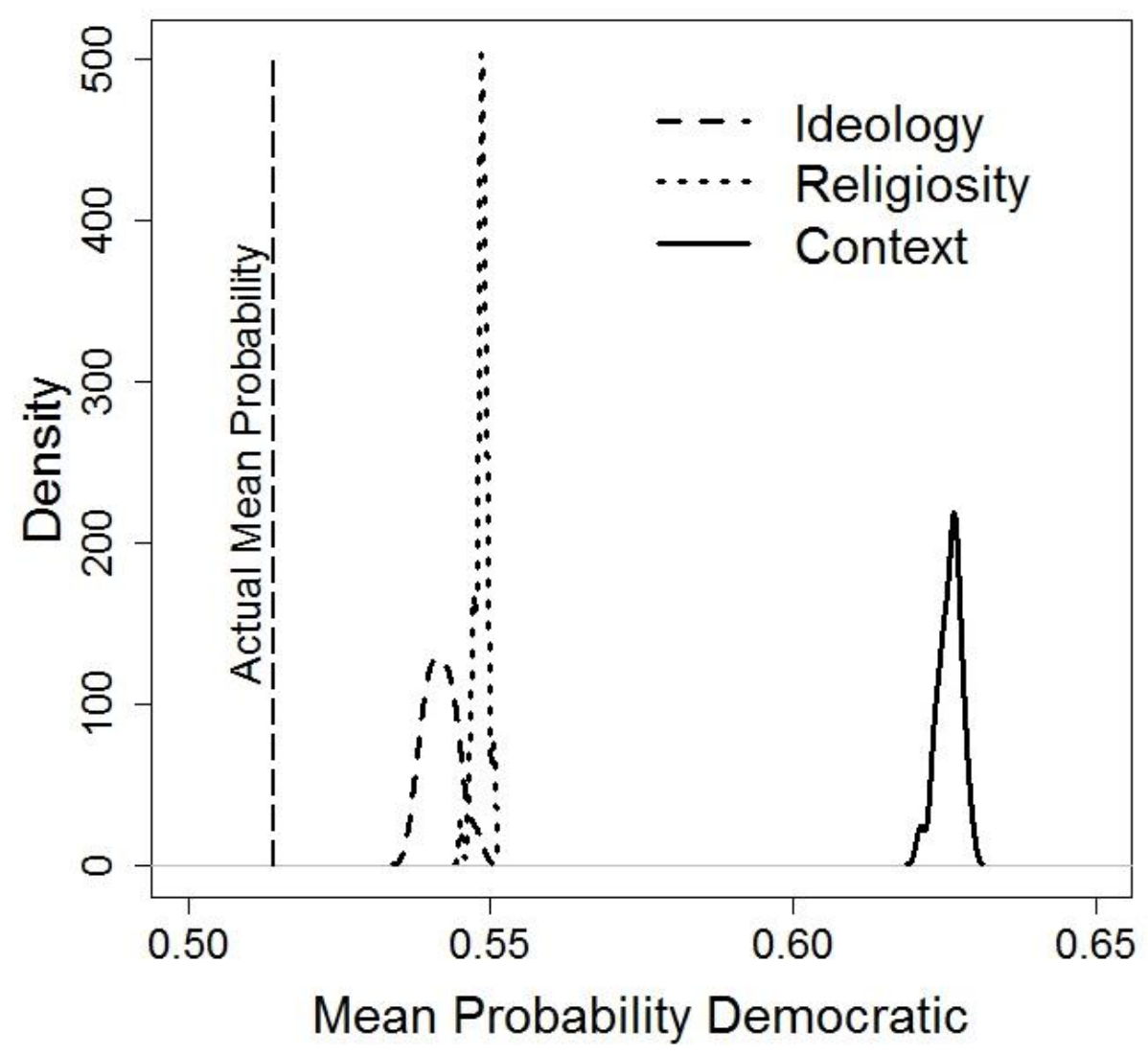

